DOI: $10.17816 /$ byusu20190433-40

УДК 544.452:535.233

The reported study was funded by RFBR according to the research projects No. 18-08-01475, 18-41-220004.

H. Z. Cui, A. A. Grigoryevskaya, P. Yu. Gulyaev

\title{
INFLUENCE OF MICROPORES ON STRUCTURAL INSTABILITY OF THE COMBUSTION WAVE
}

The article shows examples of visualization of the process of heat transfer by radiation in unstable combustion modes of porous powder materials, which are in good agreement with the results of high-speed video recording and micropyrometry. The mathematical model and the results of calculating the structure of the combustion wave in the Ni-Al system are presented. The contribution of radiative heat transfer at an adiabatic combustion temperature in the range of $8-10 \%$ and the effect of its trigger shutdown with decreasing temperature were revealed.

Key words: combustion wave, instability, heat transfer, heat radiation, visualization, SHS.

\section{Х. Ж. Чуи, А. А. Григорьевская, П. Ю. Гуляев \\ ВЛИЯНИЕ МИКРОПОРИСТОСТИ НА СТРУКТУРНУЮ НЕСТАБИЛЬНОСТЬ ВОЛНЫ ГОРЕНИЯ}

В статье показаны примеры визуализации процесса теплообмена излучением в нестабильных режимах горения пористых порошковых материалов, которые хорошо согласуются с результатами высокоскоростной видеозаписи и микропирометрии. Представлень математическая модель и результаты расчета структуры волны горения в системе Ni-Al. Выявлен вклад радиачионного теплообмена при адиабатической температуре горения $в$ диапазоне 8-10\% и эффект его триггерного отключения при понижении температуры.

Ключевые слова: волна горения, неустойчивость, теплообмен, тепловое излучение, визуализачия, СВС.

\section{Introduction}

The development of optoelectronic methods for contactless monitoring of combustion and explosion processes [1-3], based on modern television measuring systems of nanosecond resolution [4-6], allows to ensure the stability of technological modes and reproducibility of predetermined properties of materials in the process of obtaining them [7-9]. The high accuracy of micropyrometry of fast moving particles $[10 ; 11 ; 14]$, based on image recording in the charge accumulation mode, opens up the possibility of using new methods of panoramic and hyperspectral analysis in the study of explosion welding [12], heat and mass transfer in plasma [8; 13; 14] and detonation spraying [7]. The difference between the technology of self-propagating high-temperature synthesis (SHS) is that it belongs to the methods of out-of-furnace powder metallurgy and the combustion wave propagates along the charge of an exothermically reacting powder mixture [16].

The aim of the study, based on the known models of particle packing under conditions of natural bulk gravimetric density $[17 ; 18]$, is to generate the fractal structure of the mixture of initial powders for which visualization of heat transfer in the combustion wave for the 2-dimensional model taking into account local porosity and radiation heat transfer. 


\section{Description of the problem}

The foundations of computer simulation of combustion modes were laid in [16; 18], where the model consists of the heat equation and the kinetics equation:

$$
\begin{gathered}
c \rho_{0} \frac{\partial T}{\partial t}=\left(\frac{\partial^{2} T}{\partial r^{2}}+\frac{1}{r} \frac{\partial T}{\partial r}+\frac{1}{r^{2}} \frac{\partial^{2} T}{\partial \varphi^{2}}+\frac{\partial^{2} T}{\partial h^{2}}\right)+\rho_{0} Q \frac{\partial \eta}{\partial t}, \\
\frac{\partial \eta}{\partial t}=\left\{\begin{array}{cc}
k_{0}(1-\eta) \exp \left(-\frac{E}{R T}\right) & \eta<1, \\
0 & \eta \geq 1
\end{array}\right.
\end{gathered}
$$

with the generally accepted designation of physical quantities, except for cylindrical coordinates: $r$ is the radius, $\varphi$ is the polar angle, $h$ is the layer height.

The 2-dimensional model described here uses temperature for several layers of porous powder packaging:

$$
\begin{aligned}
& \frac{\partial T}{\partial t}=k\left(\frac{\partial^{2} T}{\partial x^{2}}+\frac{\partial^{2} T}{\partial y^{2}}\right)+f \\
& \frac{\partial A}{\partial t}=L\left(\frac{\partial^{2} A}{\partial x^{2}}+\frac{\partial^{2} A}{\partial y^{2}}\right) \\
& \frac{\partial B}{\partial t}=M\left(\frac{\partial^{2} B}{\partial x^{2}}+\frac{\partial^{2} B}{\partial y^{2}}\right) \\
& L=\left\{\begin{array}{c}
0: T(x, y, t)<0.2 \\
0.01 \times T(x, y, t): T(x, y, t) \geq 0.2
\end{array}\right. \\
& M=\left\{\begin{array}{c}
0: T(x, y, t)<0.2 \\
0.01 \times T(x, y, t): T(x, y, t) \geq 0.2
\end{array}\right. \\
& k=0.01
\end{aligned}
$$

Here are indicated: $T$ - layer temperature; $A_{N i}, B_{A l}$ - the corresponding concentration of the components of the mixture in the layer; the coefficients $\mathrm{k}, \mathrm{L}$, and $M$ can be set in the whole table space from the generated charge structure file [18], while the system is considered closed and adiabatic, and the heat capacity of pores is neglected. Figure 1 shows three versions of the reaction media: a clad powder $(A)$, a mixture of powders of equal size $(B)$, and a model for the Ni-Al system $(C)$. The combustion wave propagates from above, the combustion region is highlighted in red, blue and green color correspond to the initial components of the mixture, yellow to the final synthesis products. So we get the configuration of the combustion front with the allocation of coordinates of hot particles, the temperature of which is dimensionless by the value of the maximum adiabatic temperature. 


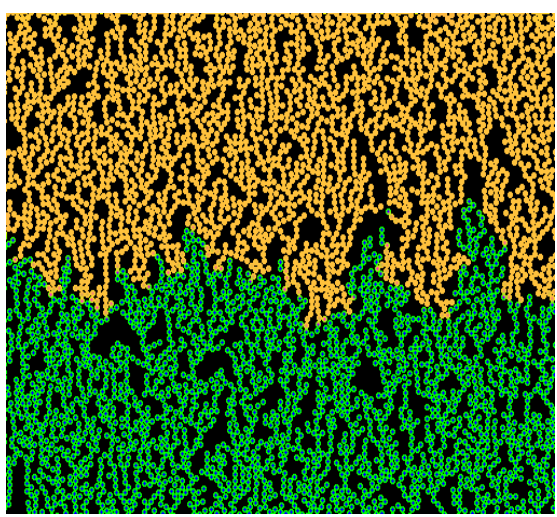

A

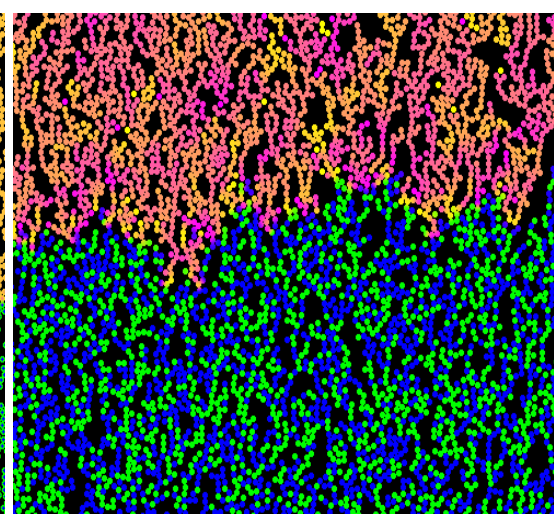

$\mathrm{B}$

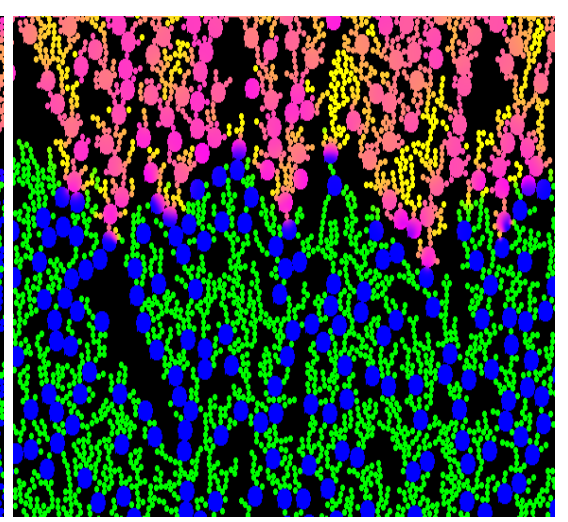

C

Figure 1. Visualization of the front of the SHS reaction wave in 2-dimensional models

Cell numbers of the graphic screen with the coordinates of the hot particles are listed. After forming the list of boundary points for each of them, a list of the remaining boundary points of the cold particles of the starting products visible from it is compiled. This is checked by the criterion for the intersection of the line connecting the selected points with any other. If the line intersects, the point is considered invisible. When calculating, according to the Stefan-Boltzmann law: $\mathrm{S}=\sigma T^{4}$, irradiation heat transfer for all boundary points, the correspondence of particle heating above the threshold temperature is checked. To do this, we believe that all effective heat transfer is carried out at a wavelength corresponding to the maximum density of thermal radiation, which is calculated according to the Wien displacement law: $\lambda_{\max }=b T^{1}$. Given that, the propagation of thermal radiation is limited in pores with a minimum diameter $d_{\min }$, in accordance with the Kirchhoff diffraction limit: $d_{\min }=\lambda_{\max } /$ $(2 n)$, restrictions are imposed on the temperature of the hot powder particles. If it is above the threshold, then it is considered that such a particle participates in radiation heat transfer and this part of the heat is transferred to points that it can irradiate. Figure 2 shows the effect of radiation heat transfer on the burning rate and the geometric shape of the reaction wave front. The results of visualization of three scenarios are presented: L ("low") - there is no irradiative heat transfer, for example, in an ultrafine powder; M ("medium") - radiation heat transfer of the order of $10 \%$, for example in ordinary fine powders; $\mathrm{H}$ ("high") - the prevailing radiation heat transfer of more than $50 \%$, for example, in loose and poorly packed powder mixtures. The numbers indicate the iteration step number when simulating the propagation of a combustion wave. It can be seen that the speed increases significantly due to warming up in the cavities of the embankment. In the complete absence of heat transfer by radiation, combustion propagates along a chain of contacting particles. 


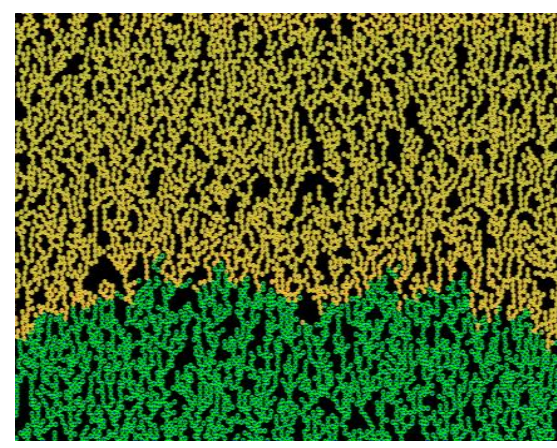

L (low); step number 7800

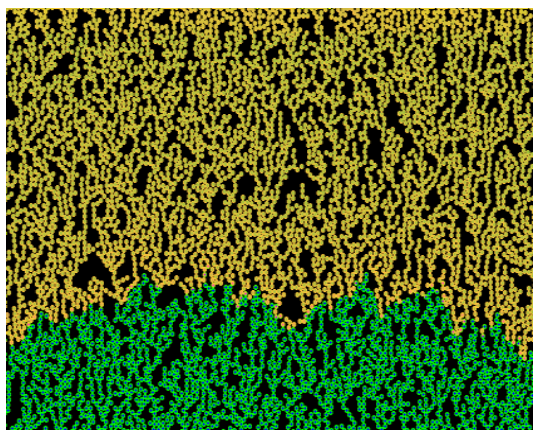

L (low); step number 7999

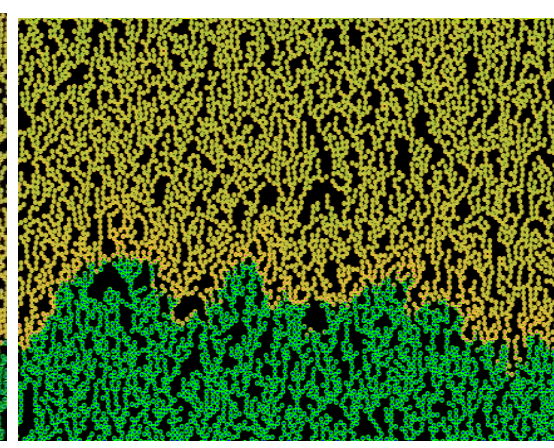

M (mid); frame number 3000

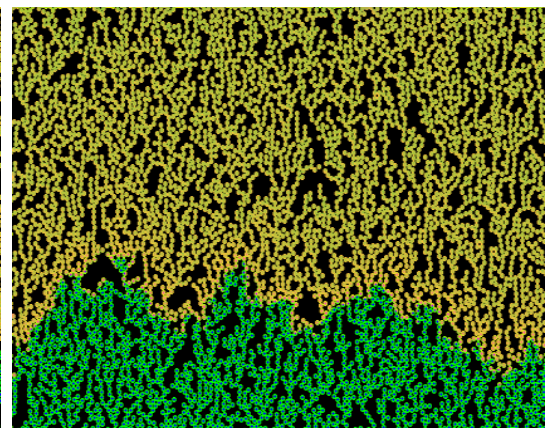

M (mid); frame number 3170

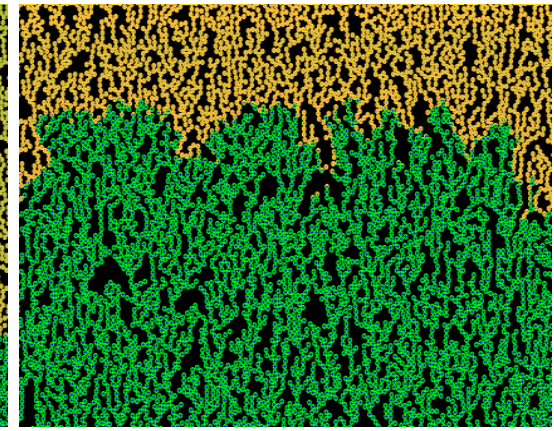

H (high); frame number 800

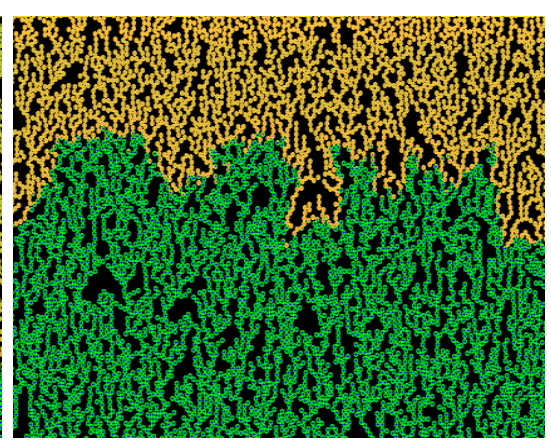

H (high); frame number 970

Figure 2. The effect of radiation heat transfer on the speed and stability of the combustion front

\section{Pore heat transfer visualization}

In the process of calculating radiation heat transfer, an array of transparency of points (obstacles) is used, the output array where the brightness, brightness of the starting point is added. The neighbors (branches) of this point are moving. Each point stores its angle and deviation from it. The sequence of the algorithm is shown in Figure 3. In the process of calculating radiation heat transfer, an array of point transparency (obstacles) is used, the output array where the brightness, brightness of the starting point is added. The neighbors (branches) of this point are moving. Each point stores its angle and deviation from it:

$$
\begin{array}{ll}
\mathrm{K}_{\mathrm{a} 1}=\mathrm{a} 1-\mathrm{b} 1 ; & \text { (minimum); } \\
\mathrm{K}_{\mathrm{b} 1}=\mathrm{a} 1+\mathrm{b} 1 ; & \text { (maximum). }
\end{array}
$$

According to them, for each point, a structure is formed storing the cone (beam) and value (beam intensity). The calculation of this branch with the input parameters of the formed structure is started. To visualize the intensity of thermal radiation, the Bayesian color optimization technique was used [19].

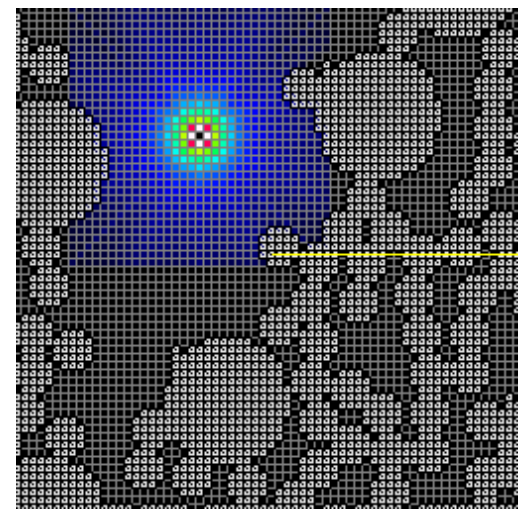

Starting hot spot

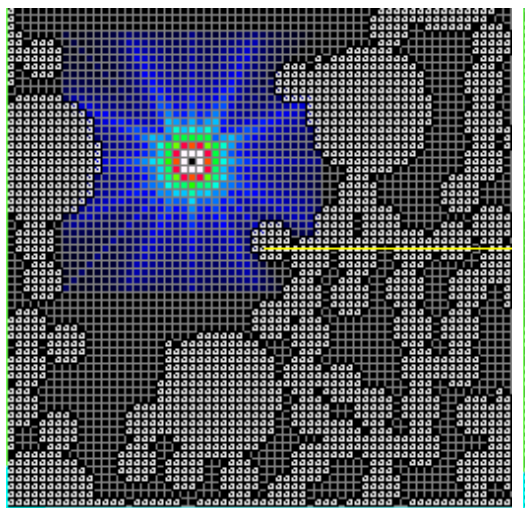

Transparency Indicatrix

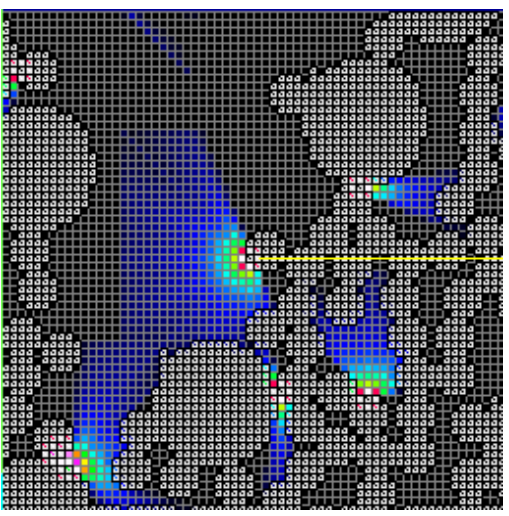

Secondary Hot Spots

Figure 3. Visualization of the indicatrix of radiation of a hot particle in pore space 
The following input parameters are used to calculate the branch: point $\left(\mathrm{p}_{\mathrm{Top}}\right)$, cone $\left(\mathrm{fK}_{\mathrm{b} 1}, \mathrm{fK}_{\mathrm{a} 1}\right)$ and beam intensity ( $\mathrm{f}_{\mathrm{Va}}$, initial beam). Zero-weighted points are skipped. The width of its input cone (window) is calculated: $\mathrm{f}_{\mathrm{Range}}=\mathrm{fK}_{\mathrm{b} 1}-\mathrm{fK}_{\mathrm{a} 1}$. If the window is zero, then the point is skipped. Next, all branches of this point are sorted. If the cone (window) of the branch $\left(\mathrm{p}_{\text {The }}\right)$ does not intersect with the cone specified by the input parameters (ray), then the point is skipped (the ray does not fall into it). If the cones intersect (beam and window), a new cone is formed from the intersection of the direction areas (the part that passes through the window is cut out of the beam). For the resulting cone (passing through the window), its width is considered: $f_{T h}=f_{\text {Max }}-f_{\text {Min }}$; The relation to the width of the initial ray is calculated: $\mathrm{f}_{\mathrm{K}}=\mathrm{f}_{\mathrm{Th}} / \mathrm{f}_{\text {Range}}$; The value is added to the storage of received radiation at this point: $+\Delta=$ $f_{V a l} * f_{K}$, where $f_{V a l}$ is the intensity of the initial beam. The calculation of its branches starts, with the parameters: this point $\left(\mathrm{p}_{\mathrm{The}}\right)$, a new cone $\left(\mathrm{f}_{\mathrm{Max}}, \mathrm{f}_{\mathrm{Min}}\right)$, a new beam intensity $\left(\mathrm{f}_{\mathrm{K}} * \mathrm{f}_{\mathrm{Val}} * \mathrm{f}_{\text {Opasity }}\right)$. Under $\mathrm{f}_{\text {Opasity }}$ is indicated the transparency of this point. If the beam intensity falls below the threshold, its branches are not considered. The result is illustrated in Figure 4, where it can be seen that the space where the study is going is looped in image Fig. 4c. Visualization of the ignition mechanism of the lower layer of particles due to radiation heat transfer is presented in Figure 5.

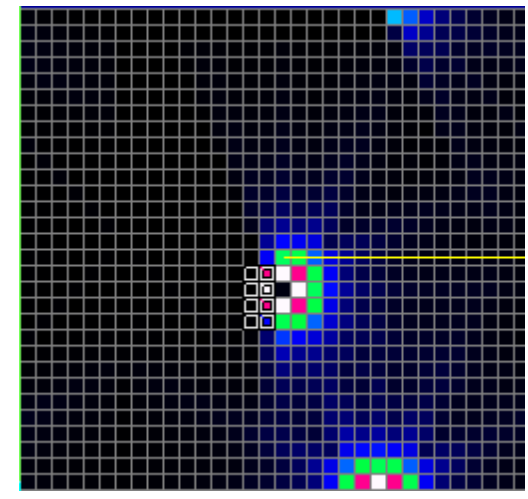

Starting point and screen

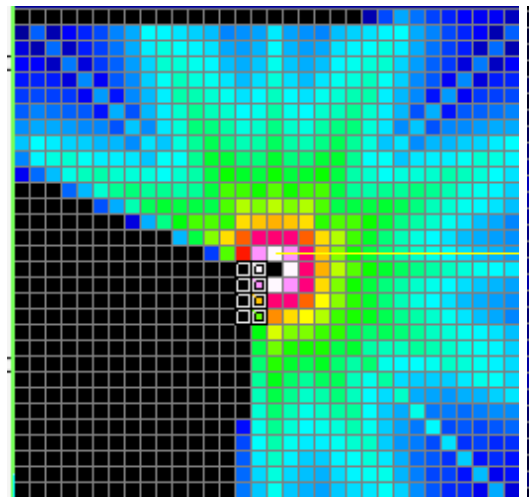

Shadow cone

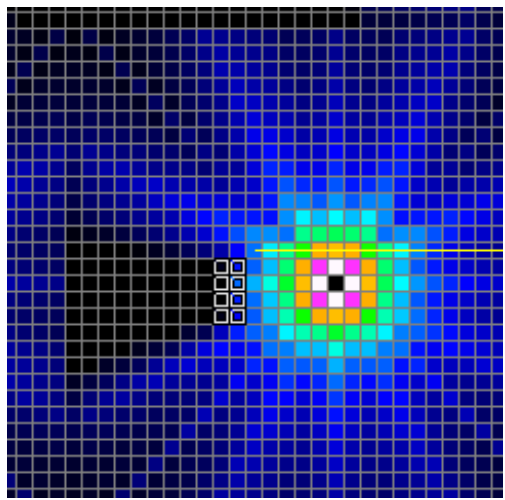

Shear radiation window

Figure 4. The sequence of formation of the shadow cone and the radiation window
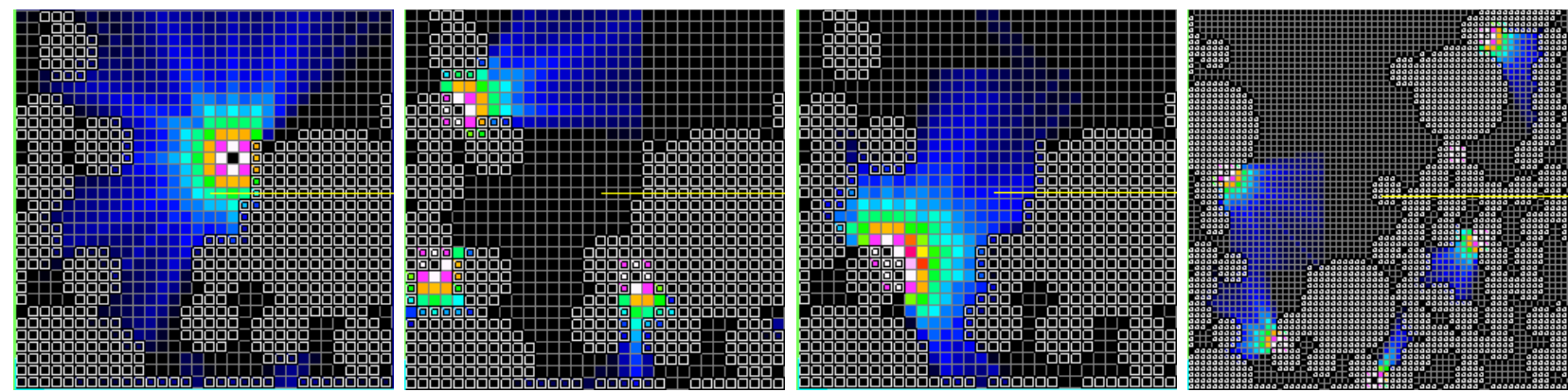

Figure 5. The mechanism of initialization of the relay mode of combustion by thermal radiation

\section{Computer Model Verification}

The adequacy of the results of computer modeling by equations (1) and (2) was checked using the porous structure of the initial mixture of $\mathrm{Ni}$ and $\mathrm{Al}$ powders as an example, as shown in Figure 6. 


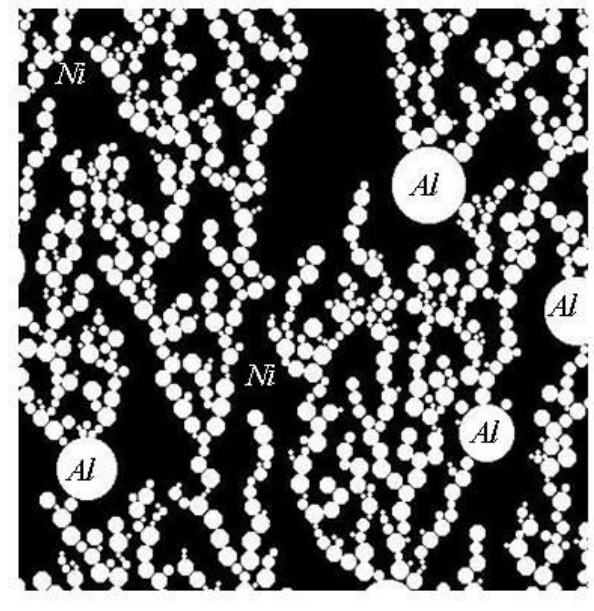

computer model

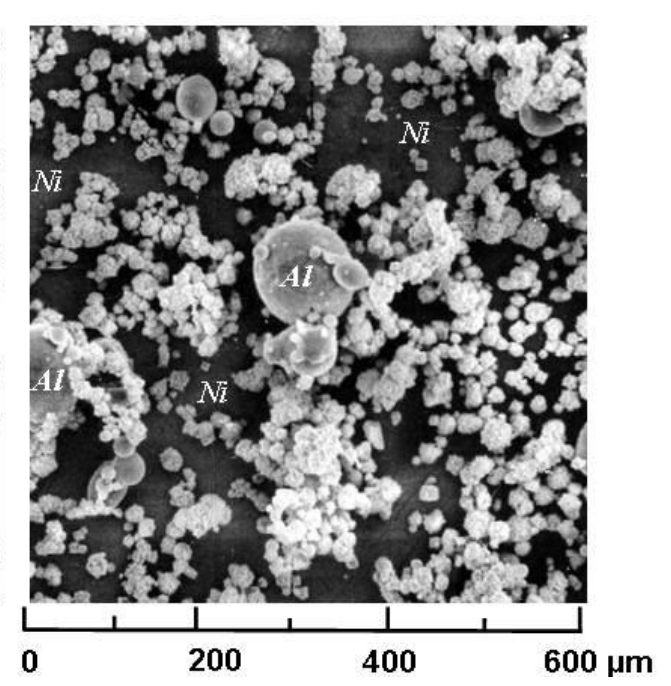

natural porous powder structure

Figure 6. Verification of the computer model by the real packing structure of powders

The computer model was compared in terms of open pycnometric porosity with a mixture of powders of carbonyl nickel, PNK-UT2 grade with a particle size of 3 to 10 microns, and aluminum, PA-4 grade with a particle size of 50 to 100 microns. As a result, the calculated values of porosity for a computer model were obtained in the range from 60 to $65 \%$. The experimentally measured porosity of a real powder mixture was 65-67\%, which indicates a good adequacy of the computer model.

The successive stages of the computer algorithm when visualizing the process of thermal radiation propagation in open pore space are shown in Figure 7.

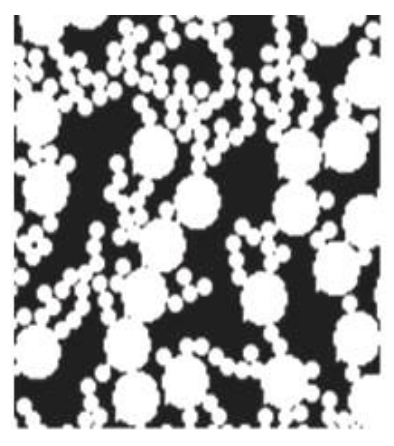

Structure transparency

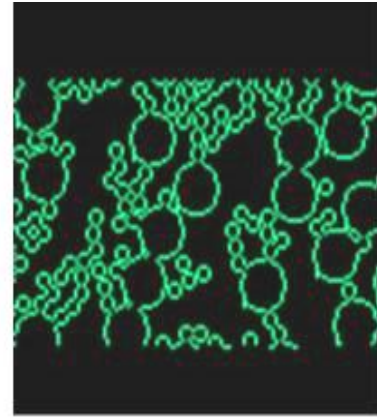

Heating visible surface

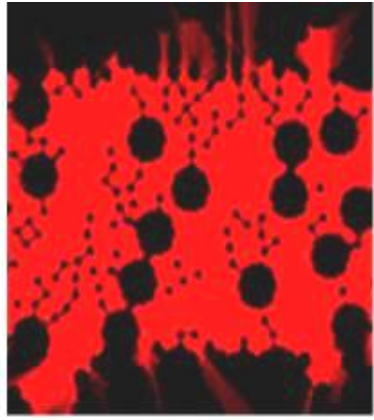

Radiation fills pores

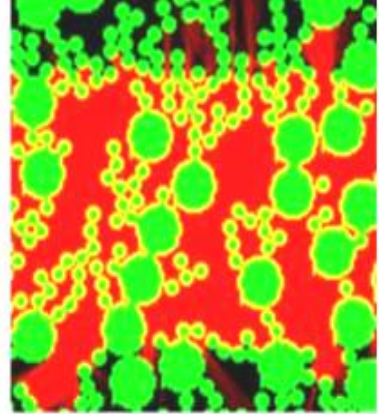

Heat localization area

Figure 7. Computer visualization of thermal radiation in the SHS combustion wave

Based on the results of computer simulation, it can be argued that thermal radiation in the combustion wave freely fills all main pores to a depth of 150-200 microns. The boundaries of the localization of thermal radiation in the region of the combustion front are pores with sizes smaller than the Kirchhoff diffraction limit: $d_{\min }=\lambda_{\max } /(2 n)$. Obviously, an increase in the effective wavelength of thermal radiation $\lambda_{\max }$ with a decrease in the combustion temperature leads to a collapse of the localization region when the size of the largest pore becomes less than $10 \lambda_{\max }$. With a characteristic heterogeneity scale $\Delta=20 \mu \mathrm{m}$, for a real mixture of powders considered in our case, in accordance with the Wien law $\lambda_{\max }=b T^{l}$, the value of the "trigger switch-off" of radiation thermal conductivity will be $1500 \mathrm{~K}[22 ; 24 ; 25]$.

\section{Conclusions}

1. The method of computer visualization of radiation heat transfer in the SHS combustion wave is in good agreement with new data and experimental results obtained using high-speed micropyrometry and thermal imaging registration of such processes in $[20 ; 21 ; 23]$. 
2. The effect of radiation heat transfer on the curvature of the combustion front (see Fig. 1C) discovered in the work can be used to develop methods for analyzing the thermal diffusion instability of combustion in the Zel'dovich - Barenblatt model for highly porous powder mixtures.

3. The contribution of radiation heat transfer at an adiabatic combustion temperature in the range of $8-10 \%$ and the effect of its trigger switching off due to the Kirchhoff diffraction threshold at a temperature below $1500 \mathrm{~K}$.

\section{References}

1. Dolmatov, A. V. Thermal imaging complex with tracking function for joint research of microheterogeneous processes and macrokinetics of SHS phenomenon / A. V. Dolmatov, P. Yu. Gulyaev. - DOI:10.1088/1742-6596/1333/6/062006 // Journal of Physics: Conference Series. - 2019. Vol. 1333. - P. 062006.

2. Гуляев, П. Ю. Физические принципы диагностики в технологиях плазменного напыления / П. Ю. Гуляев, А. В. Долматов. - Текст : непосредственный // Известия Самарского научного центра Российской академии наук. - 2009. - Т. 11. - № 5-2. - С. 382-385.

3. Гуляев, П. Ю. Методы оптической диагностики частиц в высокотемпературных потоках / П. Ю. Гуляев, А. В. Долматов, Г. Н. Леонов. - Текст : непосредственный // Ползуновский вестник. - 2012. - № 2-1. - С. 4-7.

4. Increasing the noise immunity of optical-electronic systems based on video cameras with an optical converter/ M. P. Boronenko, P. Yu. Gulyaev, A. E. Seregin, K. G. Poluhina.DOI: 10.1088/1742-6596/643/1/012028 // Journal of Physics: Conference Series. - 2015. - Vol. 643. - P. 012028.

5. Dolmatov, A. V. Investigation of structure formation in thin films by means of optical pyrometry/ A. V. Dolmatov, I. V. Milyukova, P. Y. Gulyaev. - DOI:10.1088/17426596/1281/1/012010 // Journal of Physics: Conference Series. - 2019. - Vol. 1281. - P. 012010.

6. Иордан, В. И. Оптико-электронная система диагностики двухфазных потоков динамическим методом счета частиц / В. И. Иордан. - Текст : непосредственный // Известия высших учебных заведений. Физика. - 2008. - Т. 51. - № 9-3. - С. 79-87.

7. Гуляев, П. Ю. Автоматизация контроля теплофизических параметров в технологиях детонационного напыления / П. Ю. Гуляев, А. В. Долматов. - Текст : непосредственный // Системы управления и информационные технологии. - 2009. - Т. 35. - № 1-2. - С. 230-233.

8. Методы контроля температуры и скорости частиц конденсированной фазы в процессе плазменно-дугового напыления / М. П. Бороненко [и др.]. - Текст : непосредственный // Фундаментальные исследования. 2013. - № 10-6. - С. 1194-1199.

9. In-situ selfpropagating-hightemperature-synthesis controlled by plasma / H. Z. Cui, P. Yu. Gulyaev, I. P. Gulyaev, I. V. Milyukova // Bulletin of ugra state university. - 2012. - № 2 (25). - P. 28-33.

10. Gulyaev, P. Instability of the Ni-Al combustion wave in the Zeldovich-Barenblatt parameters / P. Gulyaev, A. Dolmatov, V. Jordan. - DOI:10.1088/1742-6596/1353/1/012036 // Journal of Physics: Conference Series. - 2019. - Vol. 1353. - № 1. - P. 012036.

11. Иордан, В. И. Разрешающая способность виртуальных приборов контроля температуры частиц в плазменных потоках по суммарному спектру / В. И. Иордан. - Текст : непосредственный // Ползуновский альманах. - 2008. - № 2. - С. 13-14.

12. Saikov, I. V. Shock-wave synthesis in powder mixtures / I. V. Saikov, M. I. Alymov, P. Y. Gulyaev. - DOI: 10.1088/1742-6596/1115/4/042012 // Journal of Physics: Conference Series. 2018. - Vol. 1115. - P. 042012.

13. Бороненко, М. П. Измерение скорости и температуры частиц в потоке низкотемпературной плазмы / М. П. Бороненко. - Текст : непосредственный // Известия высших учебных заведений. Физика. - 2014. - Т. 57. - № 3-2. - С. 70-73.

14. Control of dispersed-phase temperature in plasma flows by the spectral-brightness pyrometry method / A. V. Dolmatov [at al.]. - DOI: 10.1088/1757-899X/110/1/012058 // IOP Conference Series : Materials Science and Engineering. - 2016. - Vol. 110. - № 1. - P. 012058. 
15. Phase formation time evaluation in $\mathrm{NiAl}$ combustion systems by the thermal fields visualization method / M. P. Boronenko [at al.] // Scientific Visualization. - 2015. - Vol. 7. - № 5. - P. $102-108$.

16. Ivleva, T. P. Three-dimensional modes of unsteady solid-flame combustion / T. P. Ivleva, A. G. Merzhanov // Chaos. - 2003. - Vol. 13. - Iss. 1. - P. 80-85.

17. Гуляев, П. Ю. Моделирование технологических процессов плазменного напыления покрытий наноразмерной толщины / П. Ю. Гуляев, И. П. Гуляев // Системы управления и информационные технологии. - 2009. - Т. 35. - № 1-1. - С. 144-148.

18. Моделирование фрактальных структур упаковок порошковых СВС-материалов / И. В. Милюкова, А. Л. Трифонов, С. А. Ширяев [и др.]. - Текст : непосредственный // Ползуновский альманах. - 2007. - № 3. - С. 39-41.

19. Гуляев, П. Ю. Байесовское восстановление цвета цифровых изображений / П. Ю. Гуляев, Ю. П. Гуляев, А. В. Долматов. - Текст : непосредственный // Вестник СГУГиТ. 1997. - № 2. - C. 114-115.

20. Boronenko, M. High-speed visualization of combustion synthesis discrete reaction waves: coherent heat microstructures / M. Boronenko. - DOI: 10.1088/1742-6596/1115/4/042021 // Journal of Physics: Conference Series. - 2018. - Vol. 1115. - P. 042021.

21. Dolmatov, A. V. Investigation of structure formation in thin films by means of optical pyrometry / A. V. Dolmatov, I. V. Milyukova, P. Y. Gulyaev. - DOI: 10.1088/17426596/1281/1/012010 // Journal of Physics: Conference Series. - 2019. Vol. 1281. - P. 012010.

22. Gulyaev, P. Trace-Analysis of Images of the Differential Chronogram of the Combustion Wave for Recognition of Transitional Modes of SHS / P. Gulyaev, V. Jordan // CEUR Workshop Proceedings : Optoelectronic equipment and devices in systems of pattern recognition, image and symbol information processing. Recognition. - 2017. Vol. 1940. - P. 37-44.

23. Borodina, K. Thermal analysis of reaction producing KXTiO2 / K. Borodina, S. Sorokina, N. Blinova. - DOI: 10.1007/s10973-017-6840-0 // Journal of Thermal Analysis and Calorimetry. 2018. - Vol. 131. - № 1. - P. 561-566.

24. Гуляев, П. Ю. Ттасе-анализ дифференциальной хроноскопии волны горения СВС при высокоскоростной телевизионной регистрации / П. Ю. Гуляев, В. И. Иордан, В. В. Мулярец. - Текст : непосредственный // Доклады ТУСУР. - 2018. - Т. 21. - № 1. - С. 62-67.

25. Григорьевская, А. А. Компьютерная визуализация радиационного теплопереноса в волне горения СВС / А. А. Григорьевская, П. Ю. Гуляев. - Текст : непосредственный // Ползуновский альманах. - 2019. - № 4. - С. 5-9. 